\title{
Influence of Unconventional Feedstuff on Immune Parameters in Giriraja Birds
}

\author{
J. Raghuraman ${ }^{1 *}$, M. C. Shivakumar ${ }^{2}$, H. C. Indresh ${ }^{1}$ and Jayanaik ${ }^{1}$ \\ ${ }^{1}$ Department of Poultry Science, Veterinary College, Hebbal, Bangalore, India \\ ${ }^{2}$ Department of Livestock Production Management, Veterinary College, Hassan, India \\ *Corresponding author
}

\section{Keywords}

Gut health, immune response, Newcastle disease, Broilers

Article Info

Accepted:

20 June 2021

Available Online:

10 July 2021
An experiment was conducted to study the influence of unconventional feedstuff on immune parameters in giriraja birds. A total of three hundred one day- old chicks were distributed into 5 treatment groups each consisting of 4 replicates with 15 chicks each. Basal diet $\left(\mathrm{T}_{1}\right)$ and the experimental diets were prepared by incorporating mulberry leaf powder at $5 \%\left(\mathrm{~T}_{2}\right)$, moringa leaf powder at $5 \%\left(\mathrm{~T}_{3}\right)$, sesbania leaf powderat5 $\%\left(\mathrm{~T}_{4}\right)$ and azolla powder $5 \%\left(\mathrm{~T}_{5}\right)$. The duration of the experiment was 8 weeks. Blood samples was collected from two birds from each replicate on $42^{\text {nd }}$ day. Serum was separated and antibody titer against Newcastle disease virus and Infectious bursal disease virus was estimated using HA followed by HI (Allan and Gough, 1974) and using indirect ELISA kit. In conclusion of mulberry, moringa, sesbania and azolla at 5 percent had no significant improvement on immune response against Newcastle disease and Infectious bursal disease on the $42^{\text {nd }}$ day of the experiment and also showed non-significant $(P>0.05)$ difference on immune organs weight of birds fed with different treatment groups compared to control. It was concluded that inclusion of mulberry, moringa, sesbania and azolla at 5 per cent was not beneficial in improving the immune parameters of Giriraja birds.

\section{Introduction}

Poultry industry is highly dependent on the feed price because of feed cost have a major proportion ranging between 60 to 70 per cent of total production costs. Besides, the price of conventional protein feed resources such as groundnut cake, fish meal and soybean meal are in high cost. A possible way to reduce poultry feed costs is finding alternatives to conventional protein sources that are economical, cost-effective and locally available (Shelke et al., 2018).Leaf meal do not only provide protein but also some essential vitamins $\mathrm{A}, \mathrm{C}, \mathrm{E}$, iron and minerals, amino acids(methionine, cysteine and oxycarotenoids) which are generally deficient in other feeds (Moyo et al., 2011). The use of leaf meals of plants as feed ingredients as alternative to conventional feed resources is increasingly becoming a novel area of research in animal nutrition (Abou-Elezz et al., 2011). Mulberry leaves are nontoxic natural therapeutic agents known to possess 
antidiabetic, antimicrobial, antimutagenic, antioxidant, anticancer, anxiolytic, anthelmintic, antistress, immunomodulatory, hypocholesterolemic, nephroprotective and hepatoprotective activities (Devi et al., 2013).

The higher abundance of Bacteroides, Prevotella, and Megamonas in the chicken gut suggests that using mulberry leaf powder as feed additive in chicken could be beneficial for chicken health (Chen et al., 2019). Moringa oleifera leaf meal has nutritional and medicinal values (Fahey, 2005). A study conducted of Bhattacharyya et al.(2016) repeated that Azolla pinnata possesses promising immunomodulatory potential in commercial broilers. Replacement of 5.5 per cent of basal diet with Azolla pinnata meal on dry matter basis elicit higher immunity in commercial broilers. Thus, the objective of this study was to investigate the effects of mulberry, moringa, sesbania and azolla on gut health of Giriraja birds.

\section{Materials and Methods}

The experiment was conducted at the Department of Poultry Science, Veterinary College, Hebbal, Bengaluru. A total of 300 one day old Giriraja birds were distributed into five treatment groups with four replicates in each group and fifteen birds in each replicate. Chicks were reared under deep litter system with supply of ad libitum feed and water. The trial duration was for 8 weeks (56 days). A standard broiler pre-starter, starter and finisher rations were formulated as per BIS (2007) recommendation. Basal diet $\left(T_{1}\right)$ and the experimental diets were prepared by incorporating mulberry at 5 per cent $\left(\mathrm{T}_{2}\right)$, moringa at 5 per cent $\left(\mathrm{T}_{3}\right)$, sesbania at 5 per cent $\left(\mathrm{T}_{4}\right)$ and azolla at 5 per cent $\left(\mathrm{T}_{5}\right)$. Standard managemental practice was followed during the experiment. Blood samples was collected from two birds from each replicate on $42^{\text {nd }}$ day. Serum was separated and antibody titer against Newcastle disease virus and Infectious bursal disease virus was estimated using HA followed by $\mathrm{HI}$ (Allan and Gough, 1974) and using indirect ELISA kit. At the end of the experiment, two birds from each replicate in each treatment groups were slaughtered to record the weight of lymphoid organs viz., spleen, thymus and bursa of Fabricius. The recorded weights were expressed as the percent of pre slaughter bird weight (\% of live weight).

General formula for calculation of percent relative weight of immune organ is as follows:

$$
\text { Organ weight }(\%)=\quad \frac{\text { Organ weight }(\mathrm{g})}{\text { Pre slaughter live weight }(\mathrm{g})} \times 100
$$

\section{Results and Discussion}

\section{Immunological response}

\section{Antibody titre against Newcastle disease and Infectious Bursal Disease}

At the end of $42^{\text {nd }}$ day, the antibody titre against Newcastle disease in groups $T_{1}, T_{2}$, $\mathrm{T}_{3}, \mathrm{~T}_{4}$ and $\mathrm{T}_{5}$ were $1.304,1.417,1.396,1.414$ and 1.391, respectively. ANOVA revealed no significant $(\mathrm{P}>0.05)$ difference in antibody titre against Newcastle disease among the various treatment groups and the antibody titre against Infectious bursal disease in groups $\mathrm{T}_{1}, \mathrm{~T}_{2}, \mathrm{~T}_{3}, \mathrm{~T}_{4}$ and $\mathrm{T}_{5}$ were 2559.43, 2413.56, 2498.88, 2584.66 and 2562.71, respectively. Statistical analysis revealed no significant $(\mathrm{P}>0.05)$ difference in antibody titre against Infectious bursal disease among the various treatment groups (Table 1).

\section{Immune organ weights ( $\%$ of live weight)}

The weight of spleen (\%) on $56^{\text {th }}$ day of the experiment in groups $T_{1}, T_{2}, T_{3}, T_{4}$ and $T_{5}$ were $0.124,0.128,0.131,0.133$ and 0.119 , respectively. Statistical analysis revealed no 
significant $(\mathrm{P}>0.05)$ difference in weight of spleen between the treatments and control (Table 2).

The weight of thymus $(\%)$ on $56^{\text {th }}$ day of the experiment in groups $\mathrm{T}_{1}, \mathrm{~T}_{2}, \mathrm{~T}_{3}, \mathrm{~T}_{4}$ and $\mathrm{T}_{5}$ were $0.340,0.304,0.315,0.317$ and 0.333 , respectively. ANOVA revealed no significant $(\mathrm{P}>0.05)$ difference in weight of thymus between the treatments and control (Table 2).

Table.1 Effect of supplementation of Morus alba leaf powder, Moringa oleifera leaf powder, Sesbania grandiflora leaf powder and Azolla pinnata leaf powder on antibody titers against Newcastle disease (log HI titer) and Infectious bursal disease (ELISA) on $42^{\text {nd }}$ day in Giriraja birds

\begin{tabular}{|c|l|c|c|}
\hline $\begin{array}{c}\text { Experimental } \\
\text { group }\end{array}$ & \multicolumn{1}{|c|}{ Description of the treatment } & NDV & IBDV titer \\
\hline $\mathbf{T}_{\mathbf{1}}$ & \multicolumn{1}{|c|}{ Basal diet } & $1.304 \pm 0.30$ & $2559.43 \pm 288.30$ \\
\hline $\mathbf{T}_{\mathbf{2}}$ & $\mathbf{5 \%}$ Morus alba leaves powder in basal diet & $1.417 \pm 0.18$ & $2413.56 \pm 291.49$ \\
\hline $\mathbf{T}_{\mathbf{3}}$ & $\mathbf{5 \%}$ Moringa oleifera leaves powder in basal diet & $1.396 \pm 0.22$ & $2498.88 \pm 231.06$ \\
\hline $\mathbf{T}_{\mathbf{4}}$ & $\begin{array}{l}\mathbf{5 \%} \text { Sesbania } \text { grandiflora leaves powder in basal } \\
\text { diet }\end{array}$ & $1.414 \pm 0.12$ & $2584.66 \pm 359.71$ \\
\hline $\mathbf{T}_{\mathbf{5}}$ & $\mathbf{5 \%}$ Azolla pinnata leaves powder in basal diet & $1.391 \pm 0.17$ & $2562.71 \pm 163.80$ \\
\hline
\end{tabular}

Table.2 Effect of supplementation of Morus alba leaf powder, Moringa oleifera leaf powder, Sesbania grandiflora leaf powder and Azolla pinnata leaf powder on Lymphoid organs weight (\% of live weight) (Mean \pm SE) in Giriraja birds

\begin{tabular}{|c|c|c|c|c|}
\hline \multirow{2}{*}{$\begin{array}{l}\text { Experimental } \\
\text { group }\end{array}$} & \multirow[t]{2}{*}{ Description of the treatment } & \multicolumn{3}{|c|}{ Lymphoid organs weight (g/100g body weight) } \\
\hline & & Spleen & $\begin{array}{l}\text { Bursa of } \\
\text { Fabricius }\end{array}$ & Thymus \\
\hline $\mathbf{T}_{1}$ & Basal diet & $0.124 \pm 0.150$ & $0.131 \pm 0.014$ & $0.340 \pm 0.047$ \\
\hline $\mathbf{T}_{2}$ & 5\% Morus alba leaves powder in basal diet & $0.128 \pm 0.009$ & $0.137 \pm 0.006$ & $0.304 \pm 0.040$ \\
\hline $\mathbf{T}_{3}$ & $\begin{array}{l}\text { 5\% Moringa oleifera leaves powder in basal } \\
\text { diet }\end{array}$ & $0.131 \pm 0.107$ & $0.133 \pm 0.008$ & $0.315 \pm 0.047$ \\
\hline $\mathbf{T}_{4}$ & $\begin{array}{l}\text { 5\% Sesbania grandiflora leaves powder in } \\
\text { basal diet }\end{array}$ & $0.133 \pm 0.019$ & $0.139 \pm 0.009$ & $0.317 \pm 0.027$ \\
\hline $\mathbf{T}_{5}$ & $\begin{array}{l}5 \% \text { Azolla pinnata leaves powder in basal } \\
\text { diet }\end{array}$ & $0.119 \pm 0.009$ & $0.141 \pm 0.004$ & $0.333 \pm 0.017$ \\
\hline
\end{tabular}

The weight of bursa $(\%)$ on $56^{\text {th }}$ day of the experiment in groups $\mathrm{T}_{1}, \mathrm{~T}_{2}, \mathrm{~T}_{3}, \mathrm{~T}_{4}$ and $\mathrm{T}_{5}$ were $0.131,0.137,0.133,0.139$ and 0.141 , respectively. Statistical analysis revealed no significant $(\mathrm{P}>0.05)$ difference in weight of bursa between the treatments and control (Table 2).

In similar to the present study Eze et al., (2013) who studied immune boosting potential of crude methanolic extract of Moringa oleifera in chickens experimentally challenged with Newcastle disease (ND) virus reported increases in total and differential cell numbers and haemagglutination inhibition (HI) titre in the extracts of Moringa oleifera treated groups did not correlate with total protection against ND. The present study is also in agreement with (Laxman et al., 2016) who conducted the experiment in which the average $\mathrm{HI}$ titre revealed non-significant $(\mathrm{P}>$ 0.05) differences among the experimental groups. The supplementation of moringa leaf powder in broiler diet could not exert 
significant changes in antibody titre against Ranikhet disease in broiler chickens. The present study is in disagreement with Bhattacharyya et al., (2016) who concluded that Azolla pinnata possesses promising immunomodulatory potential in commercial broilers. Replacement of 5.5 per cent of basal diet with Azolla pinnata meal on dry matter basis elicit higher immunity in commercial broilers.

\section{References}

Abou-Elezz. E., Sarmiento-Franco SantosRicalde, R. and Solorio-Sanchez. F. 2011. Nutritional effects of diet inclusion of Leucaena leucocephala and Moringa oleifera leaf meal on Rhode and Red hens' performance. Cub. J. Agri. Sci., 45:163-169.

Allan, W.H. and Gough, R.E., 1974. A standard haemagglutination inhibition test for Newcastle disease(2) Vaccination and challenge. The Veterinary Record, 95(7): 147-149.

Bhattacharyya, A., Shukla, P.K., Roy, D. and Shukla, M., 2016. Effect of Azolla supplementation on growth, immunocompetence and carcass characteristics of commercial broilers. J. Anim. Res., 6(5):941-945.

Chen, Y., Ni, J. and Li, H., 2019. Effect of green tea and mulberry leaf powders on the gut microbiota of chicken. BMC veterinary research, 15(1): 1-6.
Devi, B., N. Sharma., D. Kumar. and K.Jeet., 2013. Morus albalinn: A psycho pharmacological review. Int. J. Pharm. Pharm. Sci., 5(2): 14-18

Eze, D.C., Okwor, E.C., Okoye, J.O. and Onah, D.N., 2013. Immunologic effects of Moringa oleifera methanolic leaf extract in chickens infected with Newcastle disease virus (kudu 113) strain. African J. Pharmacy and Pharmacol, 7(31): 2231-2237.

Fahey, J. 2005. A Review of the Medical Evidence for Its Nutritional, Therapeutic, and Prophylactic Properties. Part 1. Trees Life J., 1: 5-15

Laxman, A.J., 2016. Effect of supplementation of Moringa oleifera leaf powder on performance of broilers. M.Sc. Thesis, University of Maharashtra Animal and Fishery Science, Nagpur, India.

Moyo, B., Masika, P., Hugo, A. and Muchenje, V., 2011. Nutritional characterization ofMoringa (Moringa oleifera Lam.) leaves. African $J$. Biotechnol.,10(60): 1292-1293.

Shelke, C.P.,Amrutkar, S.A., Gaikwad, N.Z., Devangare, A.A., Kulkarni, R.C., Durge, S.M., Jadhav, P.V. and Ranjan, A., 2018. Effect of Dietary Inclusion of Mulberry (Morus alba Leaf Meal) Supplemented with Multienzyme on Performance of Broiler Chicken (Doctoral dissertation, MAFSU, Nagpur).,10(18): 7126-7129.

\section{How to cite this article:}

Raghuraman, J., M. C. Shivakumar, H. C. Indresh and Jayanaik. 2021. Influence of Unconventional Feedstuff on Immune Parameters in Giriraja Birds. Int.J.Curr.Microbiol.App.Sci. 10(07): 638-641. doi: https://doi.org/10.20546/ijcmas.2021.1007.069 